\title{
ANALYSIS OF THE INFLUENCE OF ISLAMIC INCOME RATIO, TOTAL COMPREHENSIVE INCOME, AND NPF ON COMPANY VALUE WITH PROFITABILITY AS MODERATING VARIABLES IN SHARIA COMMERCIAL BANKS IN INDONESIA 2015-2019
}

\author{
Alfi Saidah1, Anton Bawono ${ }^{2}$ \\ ${ }^{12}$ Salatiga State Islamic Institute, Salatiga \\ \a2710934@gmail.com ${ }^{1}$, antonbawono@iainsalatiga.ac.id ${ }^{2}$
}

Abstract: Economic Value Added is an approach to assessing company performance, with the aim that the company's ability to create added value can influence investors who will invest in the company. The concept used in this approach is to pay attention to the funders in terms of expectations, interests, and degrees of justice as measured by weighted measures and the existing initial capital structure. The population in this study are Islamic Commercial Banks registered with the Financial Services Authority, totaling 11 Islamic Banks. In selecting the sample the method used is purposive sampling with the criteria that the author has set. The collection method in this study was carried out by looking at the annual financial statements of each Islamic bank registered with the Financial Services Authority. Based on the results of the moderation regression test, the results showed that IIR, TCI, NPF had no significant positive effect on EVA. ROA is not able to moderate IIR against EVA. ROA is not able to moderate TCI against EVA. ROA is not able to moderate NPF against EVA.

Keywords: IIR, TCI, NPF, Firm Value, ROA.

\section{INTRODUCTION}

In this modern era, the role of banks in everyday life is very much needed, because they are considered to be able to facilitate activities in social life, especially in the financial sector. The bank is an Indonesian State-Owned Enterprise that provides various types of financing and public fund management services. Sharia Commercial Banks as sharia banks which in the implementation of their activities provide services in terms of payments. In contrast to Islamic Financing Banks which are referred to as Islamic banks whose activities do not provide services in terms of payment(Law No.21 of 2008).

Sharia Bank Companies comply with (Veithzal, 2007)is a bank that is oriented and operates according to the provisions of Islamic teachings, by providing functions as a company that distributes funds to the public, and acts as an intermediary for state finances. Islamic principles in this case are promises based on the law in Islamic teachings between the funder (Bank) and the fund recipient (Customer) to provide financing storage services for the activities of a business.

Viewed from year to year the development of the banking world is very rapid, marked by the existence of various banking companies that are currently 
established and marked by the establishment of bank subsidiaries or branch offices in various regions, even in remote areas we have now met various branch offices. from various banks. Judging from the data released by the 0JK, where banking is currently an institution that carries out good supervision and regulation, it is evidence that the banking world has reached a rapid level from year to year. As evidence, with the growing network of Islamic bank creditors in Indonesia, the following is a table display of data issued by 0JK 2015-2019.

Table 1.1

Sharia Bank Office Network Growth 2015-2019

\begin{tabular}{l|c|c|c|c|c}
\hline INDICATOR & $\mathbf{2 0 1 5}$ & $\mathbf{2 0 1 6}$ & $\mathbf{2 0 1 7}$ & $\mathbf{2 0 1 8}$ & $\mathbf{2 0 1 9}$ \\
\hline BUS & & & & & \\
Total Bank & 12 & 13 & 13 & 14 & 14 \\
Total Office & 1990 & 1.869 & 1.825 & 1.875 & 1,894 \\
\hline UUS & 22 & 21 & 21 & 20 & 20 \\
Total Bank & 324 & 332 & 344 & 354 & 388 \\
Total Office & 163 & 166 & 167 & 167 & 164 \\
\hline BPRS & 446 & 453 & 441 & 495 & 506 \\
Total Bank & 2,747 & 2,654 & 2.610 & 2,724 & 2,788 \\
Total Office & & & & & \\
\hline
\end{tabular}

The table above explains that the number of Islamic banking and the number of Islamic bank offices in Indonesia has increased from year to year. There were additional 2 banks in the BUS from 2015-2019, with the number of offices decreasing by 96 office units. But in UUS there was a decrease in 2 banks, this happened because 2 banks in UUS moved to BUS, and the total offices at UUS increased by 64 offices. Meanwhile, the BPRS increased in the number of banks, namely 1 bank, and the number of offices at the BRPS increased by 60 office units.

Marked by the increasing number of Islamic banks in Indonesia, Islamic banks as financial institutions operating based on Islamic principles certainly have different characteristics from other companies in work orientation. Thus, the performance of Islamic banks in addition to being assessed using conventional methods needs to be measured using Islamic methods.

Measurement of financial performance in the company must be carried out because the measurement of financial performance is very important to find out how the performance in the company has been carried out well or not. On research (Hameed, 2004) develop a tool to measure the financial performance of Islamic banks, namely, the Islamicity Performancing Index. The purpose of this index is to find out how the financial performance of Islamic banks in Indonesia has been running according to existing Islamic principles, another purpose of this measurement is for future progress and for assessing stakeholders. Islamic banks have the same system as conventional banks. Therefore, measuring the performance of a company alone is not enough for Islamic banks, it must be balanced with the need for a company 
assessment based on Islamic aspects and must be by Islamic sharia principles, the goal is that the conventional and sharia systems are different.

Furthermore, after we know the measurement of performance with the Islamicity Performance Index, it is necessary to conduct a search for information on the financial performance of the entity for 1 period and to calculate and analyze profitability it is necessary to hold a comprehensive profit arrangement in an Islamic banking company, the goal itself is to see whether in a bank it is experiencing financing. problematic. The size of the non-performing financing (NPF) in a bank will indicate whether the performance of a bank in managing the distributed funds is good or not. If the amount of non-performing financing is very large, it will cause the profits to decrease. The following is presented data on the 2015-2019 Islamic banking NPF ratio.

Table 1.2

Sharia Bank NPF Ratio Data for 2015-2019

\begin{tabular}{c|c|c|c|c|c}
\hline \multirow{2}{*}{ Bank name } & \multicolumn{5}{|c}{ Non Performing Financing } \\
\cline { 2 - 6 } & 2015 & 2016 & 2017 & 2018 & 2019 \\
\hline BUS & $4.84 \%$ & $4.42 \%$ & $4.76 \%$ & $4.28 \%$ & $3.36 \%$ \\
\hline UUS & $3.03 \%$ & $3.49 \%$ & $2.11 \%$ & $2.34 \%$ & $3.09 \%$ \\
\hline BPRS & $8.20 \%$ & $8.63 \%$ & $9.68 \%$ & $9.02 \%$ & $8.71 \%$
\end{tabular}

Source: Statistical data on Islamic banks, December 2019.

The data above proves that the NPF ratio at BUS has decreased from 2015 to 2019 as much as $1.48 \%$, as well as the NPF ratio in UUS, in 2015 to 2019 the NPF at UUS has increased by $0.06 \%$, but different from BRPS whose NPF ratio increased from 2015 to 2019 as much as $0.51 \%$.

Table 1.3

Research Gap Research

\begin{tabular}{c|l|l|l}
\hline No & Researcher & \multicolumn{1}{|c}{ Variable } & \multicolumn{1}{c}{ Result } \\
\hline 1 & $\begin{array}{l}\text { Agustina } \\
(2014)\end{array}$ & $\begin{array}{l}\text { X: CAR, NPF, NIM, } \\
\text { LDR, BOPO } \\
\text { Y: Company value } \\
\text { Z: Profitability }\end{array}$ & $\begin{array}{l}\text { NPF has no significant negative } \\
\text { effect on firm value. }\end{array}$ \\
\hline 2 & $\begin{array}{l}\text { Hidayat } \\
\text { Sulaiman } \\
(2019)\end{array}$ & $\begin{array}{l}\text { X: Capital structure, } \\
\text { profitability, NPF } \\
\text { Y: Company value }\end{array}$ & $\begin{array}{l}\text { Capital structure and NPF do } \\
\text { not affect firm value. }\end{array}$ \\
\hline 3 & $\begin{array}{l}\text { Agnes Viana } \\
\text { Putri (2008) }\end{array}$ & $\begin{array}{l}\text { X: Comprehensive } \\
\text { income statement } \\
\text { Y: Firm value, } \\
\text { enterprise risk, and } \\
\text { financial difficulties }\end{array}$ & $\begin{array}{l}\text { Comprehensive income has no } \\
\text { significant effect on firm value. }\end{array}$ \\
\hline 4 & $\begin{array}{l}\text { Xeby } \\
\text { Winelfia } \\
\text { (2016) }\end{array}$ & $\begin{array}{l}\text { Profit, Net Income, Operating } \\
\text { and Comprehensive } \\
\text { Income } \\
\text { Y: Company Value }\end{array}$ & $\begin{array}{l}\text { Simultaneous comprehensive } \\
\text { income has value relevance and } \\
\text { has a strong influence on firm } \\
\text { value. }\end{array}$ \\
\end{tabular}

Based on the above phenomenon, there is a research gap that is shown in Agustina's research wherein her research results show that NPF has an insignificant negative effect on firm value. Meanwhile, another study 
conducted by Hidayat Sulaiman obtained different results, namely capital structure and NPF do not affect firm value. Furthermore, the second research gap is shown in Agnes Viana Putri's research wherein her research there are results that the comprehensive income variable does not have a significant effect on firm value, while research conducted by Deby Winelfia obtains the results that comprehensive income simultaneously has value relevance and has an influence strong on the value of the company.

\section{THEORY AND METHODS}

\subsection{Research Framework}

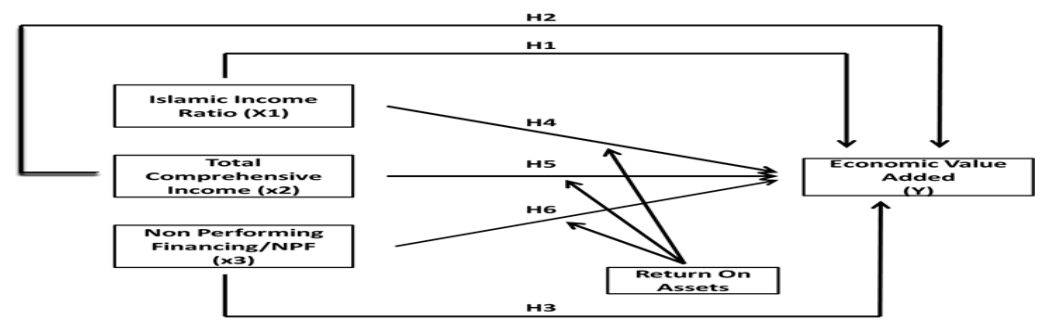

Figure 1: Research Model

According to (Eungene, 2001) a Signal signal is an action that must be taken by the company that aims to provide clues to investors about how management views the company's prospects. The signal, in this case, is in the form of information about what management has done to realize the owner's wishes. Information released from the company is an important thing because it affects the investment decisions of parties outside the company. This information is very important for investors and business people because the information essentially presents a description, notes, and descriptions, both in past, present, and future conditions as the survival of the company and its effects on the company. The information that has been published is an announcement that gives a signal to investors related to making investment decisions. So, the information from the announcement has a positive/negative nature that will make the market react (Jogiyanto, 2013).

Signal theory explains how companies can have an incentive to provide information or news from financial reports to other parties or external parties. Encouragement from companies to be able to provide information or news because there is an asymmetry in information between the company and outsiders because the company knows far more about the company \& its next project than outside parties (investors, creditors). Lack of knowledge for other parties or outsiders about a company will cause them to protect themselves more by providing a lower price for the company. The company will be able to increase the value of the company by reducing information asymmetry. (Arifin, 2005).

The next theory is intellectual capital, namely Resources Based Theory. Where this theory states that human involvement in an operational activity of the company is very important to improve performance, especially if employees are included in the formulation of the goals and daily activities of the company. The view from resources-based theory, namely intellectual 
capital meets the requirements to fulfill one of the sources of capital that will generate value-added for a company by showing it to increase revenue or profit. (Country, 2017).

\subsection{Research methods}

According to (Sugiyono, 2014b)Population is a generalization area consisting of projects or subjects that have the qualities and characteristics that have been determined by the researcher to be studied and then draw conclusions, the population is not only people but can be objects, natural objects. The population in this study is BUS registered with the OJK and BI in 2015-2019, with the number of Islamic banks registered with the OJK as many as 14 Islamic banks, and those that meet the requirements in this study are only 11 Islamic banks with the reason that of the 11 The Islamic bank has reported data according to the variables that the researcher used, and 3 of the 14 Islamic banks have not met the requirements and criteria in this study, because there are companies that do not report one of the variables that the researcher uses.

The sample is called a part of the population that has a relatively similar characteristic and is considered to be representative of the population (Sugiyono, 2014a). The sample in this study is BUS registered with the OJK which publishes monthly and published financial reports.

The technique used in sampling in this study the technique used is probability sampling, where the sampling technique provides equal space for each member of the population to be selected as a sample member. (Sujarwani, 2015). The criteria for sampling are as follows:

a. BUS registered with the OJK and BI which publishes the annual financial statements of Sharia Banks for the 2015-2019 period.

b. BUS that meets the requirements and criteria in the variables that the researcher uses, namely those that report the calculation elements of the independent, dependent, and moderating variables in this study.

\section{RESULTS AND DISCUSSION}

\subsection{Data Analysis Results}

\section{Research Instrument Test}

a. Descriptive statistics

Table 1.5

Descriptive Test Results

\begin{tabular}{l|c|c|c|c|c}
\hline & IIR & TCI & NPF & NP & ROA \\
\hline mean & 403762.0 & $2.29 \mathrm{E}+08$ & 0.672680 & 3807,262 & 0.20000 \\
\hline median & 306805.0 & $1.63 \mathrm{E}+08$ & 0.030000 & 3480,890 & 0.590000 \\
\hline Maximum & 985340.0 & $9.28 \mathrm{E}+08$ & 4.660000 & 9310.120 & 15.36000 \\
\hline Minimum & 0.053900 & 12188000 & 0.000000 & $-5585,000$ & -20.13000 \\
\hline Std. Dev. & 268694.4 & $2.12 \mathrm{E}+08$ & 1.301982 & 3311,013 & 4.241092 \\
\hline Skewness & 0.812496 & 1.556015 & 1.834130 & -0.341381 & -1.789264
\end{tabular}




\begin{tabular}{l|c|c|c|c|c} 
Kurtosis & 2.453907 & 5.225730 & 4.930576 & 3.428835 & 14.59733 \\
\hline & & & & & \\
\hline Jarque-Bera & 6.734780 & 33,54680 & 39.37829 & 1.489731 & 337.5713 \\
\hline Probability & 0.034480 & 0.000000 & 0.000000 & 0.474798 & 0.000000 \\
\hline & & & & & \\
\hline Sum & 22206909 & $1.26 \mathrm{E}+10$ & 36.99740 & 209399.4 & 11.00000 \\
\hline Sum Sq. Dev. & $3.90 \mathrm{E}+12$ & $2.43 \mathrm{E}+18$ & 91.53849 & $5.92 \mathrm{E}+08$ & 971.2904 \\
\hline & & & & & \\
\hline Observations & 55 & 55 & 55 & 55 & 55
\end{tabular}

Source: Processed secondary data, 2021

The table above shows that the average value of IIR is 403762.0 with a standard deviation of 268694.4, the lowest value is 0.053900 and the highest value is 985340.0 . TCI variable with a mean value of $2.29 \mathrm{E}+08$ and a standard deviation of $2.12 \mathrm{E}+08$, the lowest value is 12188000 , and the highest value is $9.28 \mathrm{E}+08$. The NPF variable with an average value of 0.672680 and a standard deviation of 1.301982 , the lowest value is 0.000000 and the highest value is 4.660000 . Then the variable NP (EVA) shows that the average value is 3807,262 with a standard deviation of 3311,013 , for the lowest value is $-5585,000$ and the highest value is 9310,120 . And lastly, for the Profitability (ROA) variable, the average value is 0.200000 and the standard deviation is 4.241092 , the lowest value is 20.13000 and the highest value is 15.36000 .

The table also shows that the number of data samples used is 55 data sourced from the 2015-2019 BUS financial annual reports of 11 Islamic banks.

\section{b. Stationarity Test}

This test is a test that serves to see the stationarity of the data in this study. Stationary data is constant data, to identify stationary data, one must see whether the mean, variance, and covariance of the data are constant by using a stationary test, namely the unit root test. In this study, the unit root test used was Augmented Dickey-Fuller (ADF). Decisionmaking results from the test can be declared stationary if the probability value is $<5 \%$, the following are the data from the stationarity test:

Table 1.6

Level Stationarity Test Results

\begin{tabular}{c|l|l|l}
\hline No & \multicolumn{1}{|c|}{ Variable } & \multicolumn{1}{|c}{ Prob. ${ }^{* *}$} & \multicolumn{1}{c}{ Description } \\
\hline 1. & IIR (x1) & 0.0712 & Not Stationary \\
\hline 2. & TCI (x2) & 0.7576 & Not Stationary \\
\hline 3. & NPF $(x 3)$ & 0.9834 & Not Stationary \\
\hline 4. & NP(y) & 0.0172 & Stationary \\
\hline 5. & ROA(z) & 0.0627 & Not Stationary
\end{tabular}

Source: Processed secondary data, 2021

Based on the above, it shows that the stationary data test using the $\mathrm{ADF}$ test has the probability value of one of the variables more than $5 \%$, then it continues on the ADF1st difference test, here are the results: 
Table 1.7

1st Different Level Stationarity Test Results

\begin{tabular}{c|l|l|l}
\hline No & \multicolumn{1}{|c|}{ Variable } & \multicolumn{1}{|c}{ Prob. ${ }^{* *}$} & \multicolumn{1}{|c}{ Information } \\
\hline 1. & IIR (x1) & 0.0000 & Stationary \\
\hline 2. & TCI (x2) & 0.0000 & Stationary \\
\hline 3. & NPF (x3) & 0.0150 & Stationary \\
\hline 4. & NP(y) & 0.0000 & Stationary \\
\hline 5. & ROA(z) & 0.0046 & Stationary
\end{tabular}

Source: Processed secondary data, 2021.

Stationary data testing using the ADF test level 1st difference shows the probability value $<0.05$ or $<5 \%$ the data is declared stationary and the data can be used for the next data test. The IIR variable shows a probability value of 0.0000 , the TCI variable shows a value of 0.0000 , the NPF variable shows a value of 0.0150 , the NP variable (EVA) shows a value of 0.0000 , the ROA variable shows a value of 0.0046 .

\section{Classic assumption test}

In the classical assumption, several tests must be carried out, namely the multicollinearity test, heteroscedasticity test, normality test, and autocorrelation test.

a. Multicollinearity test

The multicollinearity test was used to see if there was a close correlation between the independent variables. In research that uses more than one independent variable, multicollinearity must be avoided. The method used in this research is auxiliary, with the following formula:

$$
F i=\frac{R 2 X 1, X 2, \frac{X 3}{k}-2}{1-R 2 X 1, X 2, \frac{X 3}{n}-k+1}
$$

Information :

$\mathrm{R} 2$ = determinant coefficient

$\mathrm{n}=$ number of observations

$\mathrm{k}=$ number of independent variables

Table 1.8

Multicollinearity test results

Equation 1 (IIR C TCI NPF)

\begin{tabular}{llr}
\hline \hline MSE root & 381448.3R-squared & 0.135926 \\
Mean dependent var & -36355.07 Adjusted R-squared & 0.093776 \\
SD dependent var & 415099.5SE of regression & 395157.4 \\
Akaike info criterion & 28.67770Sum squared resid & $6.40 \mathrm{E}+12$ \\
Schwarz criterion & 28.79935Likelihood logs & -627.9094 \\
Hannan-Quinn & & \\
Criter. & 28.72282F-statistics & 3.224810 \\
Durbin-Watson stat & 2.656126Prob(F-statistic) & 0.050038 \\
\hline \hline
\end{tabular}

Source: Processed secondary data, 2021 
Calculation for IIR as an independent variable:

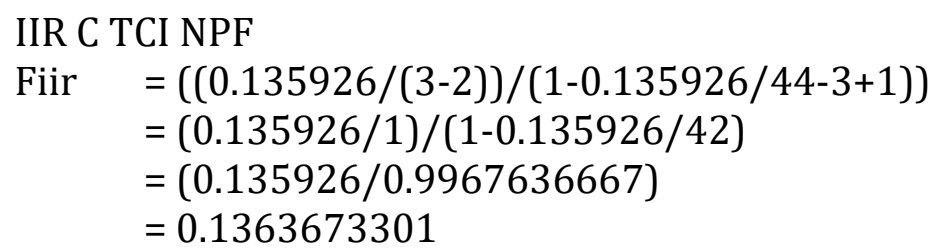

Table 1.9

Multicollinearity test results Equation 2 (TCI C IIR NPF)

\begin{tabular}{llr}
\hline \hline MSE root & 2.55E+08R-squared & 0.156917 \\
Mean dependent var & 21126433Adjusted R-squared & 0.115791 \\
SD dependent var & 2.81E+08SE of regression & $2.64 \mathrm{E}+08$ \\
Akaike info criterion & 41.68585Sum squared resid & $2.86 \mathrm{E}+18$ \\
Schwarz criterion & 41.80750Likelihood logs & -914.0886 \\
Hannan-Quinn Criter. & 41.73096F-statistics & 3.815506 \\
Durbin-Watson stat & 3.397926Prob(F-statistic) & 0.030224 \\
\hline
\end{tabular}

Source: Processed secondary data, 2021.

Ftci $=((0.156917 /(3-2)) /(1-0.156917 / 44-3+1))$

$=(0.156917 / 1) /(1-0.156917 / 42)$

$=(0.156917 / 0.996263881)$

$=0.1575054591$

Table 1.10

Multicollinearity test results

Equation 3 (NPF C IIR TCI)

\begin{tabular}{llr}
\hline \hline MSE root & 1.112470R-squared & 0.044200 \\
Mean dependent var & 0.403295Adjusted R-squared & -0.002425 \\
SD dependent var & 1.151057SE of regression & 1.152452 \\
Akaike info criterion & 3.187407Sum squared resid & 54.45398 \\
Schwarz criterion & 3.309056Likelihood logs & -67.12295 \\
Hannan-Quinn & & \\
Criter. & 3.232520F-statistics & 0.947994 \\
Durbin-Watson stat & 1.506178Prob(F-statistic) & 0.395847 \\
\hline \hline
\end{tabular}

Source: Processed secondary data, 2021.

Fnpf $=((0.044200 /(3-2)) /(1-0.044200 / 44-3+1))$

$=(0.044200 / 1) /(1-0.044200 / 42)$

$=(0.044200 / 0.998947619)$

$=0.0442465642$

The model is said to be free from if Fcount < F-table. Based on the results of the test calculations above, it is concluded by looking at the table below:

\begin{tabular}{l|l|l}
\hline F-Count & F-Table & Conclusion \\
\hline FROA $=$ & $3.23>0.1363673301$ & Free model \\
0.1363673301 & & \\
\hline $\begin{array}{l}\text { FTCI } \\
0.1575054591\end{array}$ & $3.23>0.1575054591$ & Free model
\end{tabular}


\begin{tabular}{l|l|l|} 
FNPF & $=\mid 3.23>0.0442465642$ & Free model
\end{tabular}

Source: Processed secondary data, 2021.

b. Heteroscedasticity test

The heteroscedasticity test aims to determine whether in the regression model there is an inequality of variance from the residual observations to other observations. If the variance of the residual 1 observations from other observations remains, then it is called homoscedasticity and if it is different it is called heteroscedasticity. (Ghozali, 2017). The test results can be seen in the following table:

Table 1.11

Results Heteroscedasticity test

\begin{tabular}{crrrr}
\hline \hline Variable & Coefficient & Std. Error & t-Statistic & Prob. \\
\hline \hline C & 2712.879 & 434.0489 & 6.250168 & 0.0000 \\
D(IIR) & 0.000117 & 0.001050 & 0.111139 & 0.9121 \\
D(TCI) & $2.93 \mathrm{E}-06$ & $1.57 \mathrm{E}-06$ & 1.864103 & 0.0697 \\
D(NPF) & -10.40621 & 360.0652 & -0.028901 & 0.9771 \\
\hline \hline
\end{tabular}

Source: Processed secondary data, 2021.

The table above shows the results of heteroscedasticity, where this test uses the Glejser test. Where if the probability value is less than $5 \%$, it means that heteroscedasticity occurs. The table above shows the probability value of each variable exceeding the value of $5 \%$, so it can be concluded that in this test there is no heteroscedasticity.

c. Normality test

The normality test was conducted to determine whether the regression model, residuals, or confounding variables were normally distributed or not (Ghozali, 2017). This test was performed using the Kolmogorov-Smirnov statistical test. The residual is normally distributed if it has a sig value. which is greater than the p-value of 0.05 . The test results can be seen in the following table:

Table 1.12 Normality test results

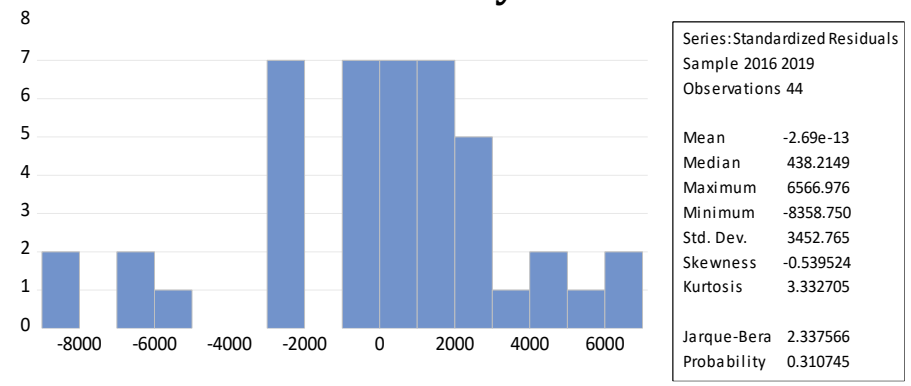

Source: Processed secondary data, 2021. 
The table above shows the results of the normality test with the Jarque-Bera probability value of 0.310745 , which means that the value is $>5 \%$ where the data is said to be normally distributed.

d. Autocorrelation Test

This assumption test aims to determine whether in a linear regression model there is a correlation between the confounding error in period $t$ and the confounding error in period $t-1$ (previous), if there is a correlation, it is called an autocorrelation problem. There are several ways to submit the autocorrelation assumption, one of which is the DurbinWaston d test (Sulhan, 2012).

Table 1.13

Autocorrelation Test Results

\begin{tabular}{|c|c|c|}
\hline MSE root & 3188,062R-squared & 0.348376 \\
\hline \multicolumn{3}{|l|}{ Mean dependent } \\
\hline var & -920.9912Adjusted R-squared & 0.198002 \\
\hline SD dependent var & $4010,608 \mathrm{SE}$ of regression & 3591,675 \\
\hline Akaike info & 19.39646Sum squared resid & $3.35 E+08$ \\
\hline Schwarz criterion & 19.71390Likelihood logs & -313.0415 \\
\hline Hannan-Quinn & & \\
\hline Criter. & 19.50327F-statistics & 2.316721 \\
\hline $\begin{array}{l}\text { Durbin-Watson } \\
\text { stat }\end{array}$ & 2.037186Prob(F-statistic) & 0.063295 \\
\hline
\end{tabular}

Source: Processed secondary data, 2021.

The results of the autocorrelation test in the table above show the Durbin-Watson value between the dU value and the 4-dU value, which is 2.037186. According to the benchmark above, it is concluded that this regression model is free from autocorrelation.

\section{Coefficient of determination test (R2)}

The coefficient of determination (R2) measures how far the model's ability to explain the variation of the dependent variable. The value of the coefficient of determination is between zero and one. If the value of the coefficient of determination (R2) is getting closer to 1 , then the effect will be stronger. The test results can be seen in the table below:

Table 1.14

Coefficient of determination test results (R2)

\begin{tabular}{llr}
\hline \hline MSE root & 3413,303R-squared & 0.253761 \\
Mean dependent var & -610.3105Adjusted R-squared & 0.108659 \\
SD dependent var & 3996,945SE of regression & 3773,549 \\
Akaike info criterion & 19.47238Sum squared resid & $5.13 \mathrm{E}+08$ \\
Schwarz criterion & 19.79678Likelihood logs & -420.3925 \\
Hannan-Quinn Criter. & 19.59269F-statistics & 1.748849 \\
Durbin-Watson stat & 2.900981Prob(F-statistic) & 0.128601 \\
\hline
\end{tabular}


Sources of processed secondary data, 2021.

The table above shows the acquisition of R2 or R-Squared0.253761. This shows that the level of influence of the independent variable on the dependent variable is $25.3761 \%$, while the remaining $74.6239 \%$ (100\% $25.3761 \%$ ) is explained by other variables outside of this regression model research.

\section{T Uji test}

The t-test aims to determine whether partially the independent variables used in the model affect the dependent variable. Conditions concluded that partially independent variables affect the dependent variable is if the significance value is less than 0.05 .

Table 1.15

T. Test Results

\begin{tabular}{crrrr}
\hline \hline Variable & Coefficient & Std. Error & t-Statistic & Prob. \\
\hline \hline C & -978.5580 & 624.2845 & -1.567487 & 0.1257 \\
D(IIR) & -0.002355 & 0.001658 & -1.420382 & 0.1641 \\
D(TCI) & $-4.96 \mathrm{E}-07$ & $2.51 \mathrm{E}-06$ & -0.197400 & 0.8446 \\
D(NPF) & 239,5861 & 703.3186 & 0.340651 & 0.7353 \\
D(ROA) & -157.9089 & 5547354 & -0.284656 & 0.7775 \\
D(IIR_ROA) & 0.000452 & 0.001140 & 0.396261 & 0.6943 \\
D(TCI_ROA) & $1.59 \mathrm{E}-06$ & $1.14 \mathrm{E}-06$ & 1.401936 & 0.1695 \\
D(NPF_ROA) & -116.5815 & 864.5663 & -0.134844 & 0.8935 \\
\hline \hline
\end{tabular}

Source: Processed secondary data, 2021.

\subsection{Discussion}

1. IIR to Firm Value (EVA)

The variable IIR (Islamic Income Ratio) shows at t count -1.420382 which means it has a negative effect with a significance value of $0.1641<0.05$, then IIR is said to have no significant negative effect on firm value. When there is a decrease or increase in IIR, there is no effect on the EVA that is distributed. These results can be said that $\mathrm{H} 1$ is rejected, which means that the IIR variable has a significant negative effect on EVA. IIR is part of the Islamic performance index which serves to measure the level of the company's financial performance. The published financial statements of Islamic banks have included the accounting guidelines set by the BUS policy. This study found that the Islamic Income Ratio was not able to negatively affect EVA significantly. So if the financial performance measured using IIR in the assessment does not get good results, it will have an impact on the value of the company, especially in the eyes of investors, it will also get a bad assessment. On the other hand, if the measurement of financial performance (IIR) is considered satisfactory, it will have a good impact on firm value (EVA) and investors will give a positive value to the measurement of financial performance.

2. Total Comprehensive Income (TCI) to Firm Value (EVA)

The TCI variable shows the t-count -0.197400 at a significance level of $0.8446>$ 0.05 , meaning that the TCI variable does not have a significant negative effect on 
firm value, that when there is an increase or decrease in TCI, there is no effect on the EVA distributed. It can be concluded that every company that reports an increase or decrease in a company's comprehensive income in its annual report does not affect the company's valuation (economic value added), as well as a company that does not report the results of an increase or decrease in a company's comprehensive income in terms of its income. the annual report, this will also not affect the company's assessment (economic value added). From these results, it can be interpreted that $\mathrm{H} 2$ is rejected,

3. Non-Performing Financing (NPF) to Firm Value (EVA)

The NPF variable shows at $t$ count 0.340651 with a significance level of $0.7353>$ $5 \%$, then the NPF is statistically said to have no significant positive effect on EVA. This means that when there is an increase or decrease in the NPF, there is no effect on the EVA being distributed. From these results, it can be interpreted that H3 is rejected, where NPF has no positive effect on EVA. Non Performing Financing is a financial ratio that is used as a measure of a bank's ability to cover the bank's risks in failing to repay debt (credit) to debtors (debtors). In this case, if the company has a high level of Non-Performing Financing, it will have an impact on a bad assessment by investors. Otherwise,

4. ROA Moderates Islamic Income Ratio (IIR) to Firm Value (EVA)

Variable IIR shows at t-count 0.396261 , with a significance value of $0.6943>5 \%$, then ROA does not moderate IIR in a significantly positive manner on EVA. This study strengthens $\mathrm{H} 4$ which means that ROA is not able to moderate IIR against EVA. Obtaining company size can be seen to what extent total assets are integrated into financing and receivables that Islamic banks have, this has not been considered good when viewed using Islamic financial performance measurement (Islamic Income Ratio) because the acquisition of this study proves that increasing company size (ROA ) which is not matched by an increase in financial performance (IIR) so that the financial performance is considered unsatisfactory. These results prove that firm size (ROA) cannot moderate the significant positive relationship between financial performance and firm value.

5. ROA Moderates the Effect of Total Comprehensive Income (TCI) on Firm Value (EVA)

TCI variable shows t-count 1.401936 with a significance level of $0.1695>0.05$, which means that ROA does not moderate the TCI positively significantly on EVA. This study weakens $\mathrm{H} 5$ which means that ROA is not able to moderate TCI to Firm Value (EVA). The purpose of compiling comprehensive income is to obtain information on the company's financial performance in one period, this is useful for calculating and analyzing the company's profitability. Comprehensive income has a close relationship with the company's overall income which will describe how the company's value is. So, if a company has a good comprehensive income, it will increase the profitability of the company and become an interest for investors to buy shares in the company. even though the price is high, investors do not hesitate to buy the stock. Because they have seen how the company is performing.

6. ROA Moderates the Effect of NPF on Firm Value (EVA)

NPF shows at t-count -0.134844 with a significance value of $0.8935>5 \%$, then ROA does not moderate NPF significantly negatively on EVA. This study strengthens $\mathrm{H} 6$ which means that ROA is not able to moderate NPF on Firm 
Value (EVA). If in a company the NPF value increases, the ROA in the company will get worse and smaller. This is due to an increase in NPF which will result in the company losing opportunities to earning profits or earning costs that have been incurred, eventually, it will affect the acquisition of income or profit and will have a negative impact on the profitability (ROA) of Islamic banks A company is said to have a high NPF or non-performing financing when the company has a level of non-performing financing that is much greater than the total credit or financing disbursed to the recipient (the debtor). When the company has a high NPF, the costs incurred by the company will increase, also known as the larger the bank's NPF, the worse the company's performance will be, and investors will give a bad assessment of the company's performance.

\section{CONCLUSION}

The results of this study indicate that the IIR, TCI, and NPF variables do not affect Firm Value, and Profitability (ROA) does not moderate IIR, TCI, NPF on Firm Value at Islamic Commercial Banks for the 2015-2019 period. With the acceptance of nonhalal income, the bank gives an unfavorable assessment of investors, so that the profitability of Islamic banks decreases. 


\section{REFERENCE}

Agustina, LAA 2014. The Influence of CAR, NPL, NIM, LDR, and OEOI on Firm Value With ROA as an Intervening Variable in Go Public Commercial Banks in Indonesia for the 2008-2012 Period. Thesis, Diponegoro University.

Arifin, Zaenal. 2005. Theory of Finance and Capital Markets. economy microphone.

Eugene F, B. And Joel F. Houston. 2001. Financial Management. Erlangga.

Ghozali, Imam. 2017. Application of Multivariate Analysis with IBM SPSS 23 Program. Semarang: BPFE Diponegoro University. IOSR Journal of Economics and Finance.

Hamid, S. et al. 2004. Untitled. Alternative Disclosures and Performance Measures for Islamic Banks Second Conference Administration.

Yogyakarta. 2013. Business Research Methodology: Misconceptions and Experiences.

State, et al. 2017. Resource-Based Competitive Advantage Theory: Implications for Strategy Formulation. California Management Review. https://doi.org/10.2307/41166664

Putri, A, V. 2008. Scientific Articles Scientific Articles. Journal of Accounting Analysis, 4 (672013167), 0-18.

Sugiyono. 2014a. Research Methods and Procedures. E-Journal.

Sugiyono. 2014b. Population and sample. Quantitative Approach to Educational Research Methods, Qualitative and R\&D.

Sugiyono. 2017. Quantitative, Qualitative, and R\&D Research Methods. Bandung: PT Alphabet. In Sugiyono. (2017). Quantitative, Qualitative, and R\&D Research Methods. Bandung: PT Alphabet.

Law No.21. 2008. Law Number 21 of 2008 concerning Islamic Banking. State Law of the Republic of Indonesia.

Veithzal, R., and others. 2007. Management of Banks and Financial Institutions. Jakarta: PT. King Grafindo Persada.

Winelfia, D. 2016. Untitled اسمقتر حلتقيمجودةخدماتالملحقياتالتقافيةالمقدمةللطلاب. Winelfia, D. (2016), 147, 11-40.

wiratna sujarwani. (2015). business and economic research methodologies.

(www.idx.co.id). 2019. Annual Financial Report. 2015-2019 Annual Financial Report.

www.bankmuamalat.co.id. accessed on 28 january 2021, 08.34 .

www.banknetsyariah.co.id. accessed on 28 january 2021, 0836.

www.bankvictoriasyariah.co.id. accessed on 28 january 2021, 08.39.

www.bcasyariah.co.id. accessed on 28 january 2021, 08.43.

www.bjbsyariah.co.id. accessed on 28 january 2021, 08.48 . 
www.bnisyariah.co.id. accessed on 28 january 2021, 08.51.

www.brisyariah.co.id. accessed on 28 january 2021, 08.56.

www.mandirisyariah.co.id. accessed on 28 january 2021, 09.03.

www.megasyariah.co.id. accessed on 28 january 2021, 09.10 .

www.paninbanksyariah.co.id. accessed on 28 january 2021, 09.12.

www.bankbukopinsyariah.co.id. accessed on 28 january 2021, 09.16. 
Halaman ini sengaja dikosongkan 